\title{
Production of a toxic metabolite in 2,4-D-resistant GM crop plants
}

\author{
Paul F. Lurquin ${ }^{1,2}$
}

Received: 8 August 2015/Accepted: 24 October 2015/Published online: 23 February 2016

(c) The Author(s) 2016. This article is published with open access at Springerlink.com

\begin{abstract}
This Note questions the safety of crop plants engineered with transgenes coding for the degradation of the herbicide 2,4-dichlorophenoxyacetic acid (2,4-D) into its cytotoxic metabolite 2,4-dichlorophenol (2,4-DCP).
\end{abstract}

Keywords Herbicide resistant crop plants . 2,4-dichlorophenol toxicity $\cdot$ 2,4-dichlorophenoxyacetic acid $\cdot$ 2,4-dichlorophenoxyacetic acid metabolites . Food safety

The herbicide 2,4-dichlorophenoxyacetic acid (2,4-D) was developed in the 1940s and used on a large scale for several decades. It has more recently been supplanted in agricultural markets by herbicides such as glyphosate and glufosinate. However, the appearance of weeds resistant to these herbicides has prompted biotech companies to engineer crop plants with transgenes conferring resistance to two herbicides, not just one. This would considerably delay the formation of herbicide-resistant mutant weeds. To that effect, Dow AgroSciences has recently released transgenic soybeans and corn resistant to both the herbicides dicamba or glyphosate and 2,4-D. These crops are described in layman's terms in their website at http://www.enlist.com/en/how-itworks/enlist-traits. It should be noted that the author of this Note is not generally opposed to GM crop plants. Rather, he is of the opinion that scientific evidence should prevail in the release or rejection of such crops (see Lurquin 2001, 2002).

Paul F. Lurquin

Lurquin@wsu.edu

1 School of Molecular Biosciences, Washington State University, Pullman, WA 99164, USA

2 c/o PO Box 369, Cannon Beach, OR 97110, USA
The idea of engineering 2,4-D resistance in plants is not new. A scenario to achieve this goal was presented by us in February 1985 at a symposium of the Weed Science Society of America in Seattle, Washington. This scenario was subsequently published in the peer-reviewed journal Weed Science (Perkins et al. 1987). Our reasoning was based on the ability of certain soil bacteria to degrade 2,4D all the way to succinate (Fig. 1), a useful compound member of the Krebs cycle. To that effect we proposed to clone and transfer to plants one or more $t f d$ genes from the soil bacterium known at the time as Alcaligenes eutrophus. This bacterial species is now known as Cupriavidus necator. Plasmid pJP4 harbored by C. necator 134 carries six genes designated $t f d A-F$ that code for the degradative pathway of 2,4-D (Don and Pemberton 1985). The first gene of the pathway, $t f d A$, codes for an oxygenase that converts 2,4-D into 2,4-dichlorophenol (2,4-DCP) (Fig. 1). C. necator 134 grown in the presence of 2,4-D does indeed produce 2,4-DCP (Perkins et al. 1987). Interestingly, we first demonstrated that 2,4-DCP is much less toxic to plants than 2,4-D (Perkins et al. 1987). This observation was confirmed by others years later (Taylor et al. 1989). Thus, we reasoned that plants engineered with $C$. necator's $t f d A$ gene would convert phytotoxic 2,4-D into much less phytotoxic 2,4-DCP, hence rendering these plants resistant to the herbicide. This was indeed shown to be the case (Streber and Willmitzer 1989; Lyon et al. 1989; Bayley et al. 1992). Dow Agrosciences' recently released 2,4D resistant transgenic corn and soybeans were engineered with C. necator's tfdA homologs isolated from Sphingobium herbicidivorans and Delftia acidovorans and thus produce 2,4-DCP (Wright et al. 2010).

Unfortunately, much reduced phytotoxicity does not necessarily mean that $t f d A$-(or analogous) containing 2,4D resistant crop plants are safe for consumption. Indeed, 2,4- 


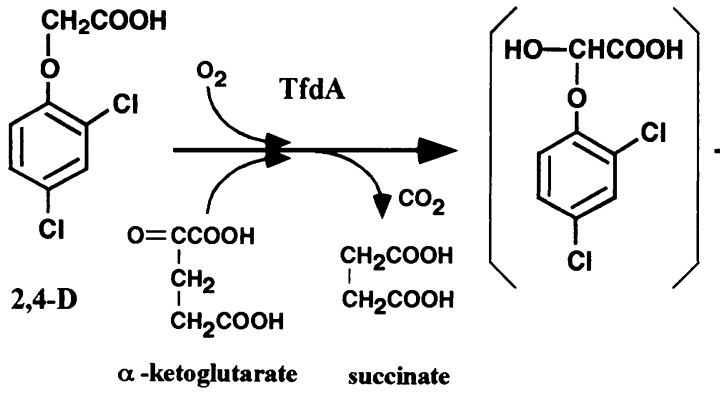

Fig. 1 Partial catabolism of 2,4-dichlorophenoxyacetic acid (2,4-D) by the two enzymes coded for by $t f d A$ and $t f d B$. 2,4-DCP 2,4dichlorophenol; 3,5-DCC 3,5-dichlorocatechol. TfdA (the product of the $t f d A$ gene) converts phytotoxic 2,4-D into much less phytotoxic 2,4-DCP (Perkins et al. 1987). The latter is toxic to a variety of animal cells, however (see text). TfdB converts 2,4-DCP into 3,5-DCC, a compound that still displays phytotoxicity (Liao et al. 2006). Tobacco plants transgenic for $t f d B$ exist (Perkins et al. 1990a, b) but have not been used in phytotoxicity studies. Human toxicity of $3,5-\mathrm{DCC}$ is

DCP is cytotoxic to a variety of animals and animal cell lines. The International Agency for Research on Cancer (IARC), a branch of the World Health Organization, has categorized 2,4-DCP as a compound belonging to group $2 \mathrm{~B}$, that is, "a possible carcinogen based on inadequate evidence in humans and limited evidence in experimental animals." But in fact, the IARC in 2015 also designated 2,4-D as a group 2B compound (http://www.iarc.fr/en/media-centre/pr/2015/ pdfs/pr236E.pdf). However, a meta-analysis of the literature (Goodman et al. 2015) does not support an association between 2,4-D and non-Hodgkin's lymphoma, gastric cancer, or prostate cancer, as proposed earlier by some. Such meta-analysis does not seem to exist for 2,4-DCP and cancer risk. Nevertheless, extensive reports reviewing the earlier literature up to about the year 2000 and published by the IARC (http://monographs.iarc.fr/ENG/Monographs/vol71/ mono71-34.pdf) and the Japanese Ministry of Economy, Trade and Industry (http://www.meti.go.jp/english/report/ downloadfiles/gED0307e.pdf) both agree that 2,4-DCP presents low acute toxicity when delivered orally in mice and rats. For example, in rats, no effect on survival is seen after 13 weeks on $2000 \mathrm{mg} / \mathrm{kg} / \mathrm{day}$. In mice, no mortality is observed after 13 weeks on $2600 \mathrm{mg} / \mathrm{kg} / \mathrm{day}$ (Syracuse Research Corporation 1992; also see Gorzinski et al. 1987). In addition, both reports indicate the absence of evidence linking 2,4-DCP and tumorigenesis in experimental animals. Further, 2,4-DCP registers negative in the Ames test but scores positive in the sister chromatid exchange test in $\mathrm{CHO}$ cells in vitro (see the National Toxicology Program 1989). 2,4-DCP also scores positive in the aneuploidy test with Chinese hamster V79 lung cells in vitro and induces mutations in the $t k$ gene in mouse lymphoma L5178Y cells also in vitro. (see the IARC report for references to all these observations). present but information is scant. According to its Material Safety Data Sheet (MSDS) 3,5-DCC can cause eye, skin and respiratory irritation. The remaining phytotoxicity of 3,5-DCC can be reduced by inserting the third gene of the pathway, $t f d C$ (Liao et al. 2006). TfdC converts 3,5-DCC into dichloro cis, cis-muconate by opening the aromatic ring (not shown). The human toxicity of dichloro cis, cis-muconate is unknown. Introducing the whole 2,4-D degradation pathway into plants would allow them to convert 2,4-D into succinate and acetyl coA (Perkins et al. 1990a)

More recently, 2,4-DCP has been linked to a variety of negative metabolic and additional genotoxic effects. For example, 2,4-DCP injected intraperitoneally into Swiss mice at one half the LD50 $(180 \mathrm{mg} / \mathrm{kg})$ displayed chromosome aberrations in bone-marrow and spermatocyte cells. 2,4-DCP also induced sperm head abnormalities in these animals (Amer and Aly 2001). Further, 2,4-DCP induces apoptosis in L929 mouse cells (Chen et al. 2004) and grass carp primary hepatocytes (Li et al. 2013), inhibits antioxidant enzyme activities in human erythrocytes in vitro (Bukowska 2003), exhibits androgenic effects potentiated by dihydrotestosterone in human prostate cancer cells (Kim et al. 2005) and interferes with the transcription of genes involved in steroidogenesis in H295R human adrenocortical carcinoma cells in vitro (Ma et al. 2012). Ma et al. (2012) also observed disruption of endocrine function in zebrafish in vivo. Also, negative reproductive effects were observed in a two-generation study in 2,4-DCP-treated Wistar-Hannover rats (Aoyama et al. 2005). Another report shows that 2,4-DCP induces global DNA hypermethylation in the liver of goldfish (Zhang et al. 2014). The use of fish species in some of the studies is not surprising as 2,4-DCP is a pollutant found in industrial effluents.

In view of some of the noxious properties displayed by 2,4-DCP already known over a decade ago, serious concerns regarding the safety of 2,4-D resistant crops producing 2,4-DCP were voiced earlier (Lurquin 2001, 2002). To try to circumvent the toxicity of 2,4-DCP, we advocated the further engineering of 2,4-D resistant plants with downstream catabolic genes, such as $t f d B$ and beyond (Lurquin 2002). To that effect, we have cloned and sequenced the $t f d B$ and $t f d C-F$ operons from pJP4 (Perkins et al. 1988, 1990a). For example, Fig. 1 shows that the 
product of $t f d B$ converts 2,4-DCP into 3,5-dichlorocatechol (3,5-DCC) which may be less toxic than 2,4-DCP. However, even this step does not totally solve the problem of 2,4-DCP's permanence in resistant plants. Indeed, it has been shown (Perkins et al. 1990b) that tobacco plants transgenic for $C$. necator's $t f d B$ fail to convert all their fed 2,4-DCP into 3,5-DCC, possibly as a result of 2,4-DCP's affinity for cellular structures and/or metabolization that limit access to the $t f d B$ gene product. In fact, Laurent et al. (2007) demonstrated that non-transgenic tobacco cells in suspension culture incubated with radiolabeled 2,4-DCP form glycoside and glucoside conjugates of the latter. This, write these authors, might be problematic, as these conjugates, when consumed by animals and humans, may release 2,4-DCP in hydrolysis reactions in their digestive tracts.

In conclusion, the safety of 2,4-D resistant crop plants remains a controversy. It behooves biotech companies responsible for the release of 2,4-D resistant crops, as well as federal agencies, to fully disclose to the public the results of extensive toxicology studies with these crops. Unfortunately, Wright et al. (2010), the creators of 2,4$\mathrm{D}$ resistant corn and soybeans, do not discuss the accumulation and fate of 2,4-DCP in their article and neither does Dow AgroSciences' relevant website (http://www. enlist.com/en/how-it-works/enlist-traits).

As mentioned above, the full degradative pathway of 2,4-D has been cloned and sequenced (Perkins et al. 1990a). Thus, nothing prevents biotechnologists from transferring several $t f d$ genes into target crop plants to make them safer for human consumption. As a first step in that direction, Liao et al. (2006) have shown that plants transgenic for $t f d C$ can detoxify 3,5-DCC, the second metabolite in the 2,4-D degradative pathway (Fig. 1), by converting it to dichloro cis, cis muconate. They also showed that Arabidopsis thaliana plants possess $t f d D$ and tfdE orthologs whose products are seemingly able to further catabolize cis, cis muconate. It is not known whether 2,4-D resistant GM corn and soybeans harbor such orthologs. Thus, biotech companies should take advantage of transferring several $t f d$ genes (or analogs) into target crop plants instead of releasing potentially harmful GM crops prematurely.

\section{Compliance with ethical standards}

Conflict of interest The author declares no conflict of interest.

Open Access This article is distributed under the terms of the Creative Commons Attribution 4.0 International License (http:// creativecommons.org/licenses/by/4.0/), which permits unrestricted use, distribution, and reproduction in any medium, provided you give appropriate credit to the original author(s) and the source, provide a link to the Creative Commons license, and indicate if changes were made.

\section{References}

Amer SM, Aly FAE (2001) Genotoxic effect of 2,4-dichlorophenoxyacetic acid and its metabolite 2,4-dichlorophenol in mouse. Mutat Res 494:1-12

Aoyama H, Hojo H, Takahashi KL, Shimizu N, Araki M, Harigae M, Tanaka N, Shirasaka N, Kuwaraha M, Nakashima N, Yamamoto E, Saka M, Teramoto S (2005) A two-generation reproductive toxicity study of 2,4-dichlorophenol in rats. J Toxicol Sci 30:59-78

Bayley C, Trolinder N, Ray C, Morgan M, Quisenberry JE, Ow DW (1992) Engineering 2,4-D resistance into cotton. Theor Appl Genet 83:645-649

Bukowska B (2003) Effects of 2,4-D and its metabolite 2,4dichlorophenol on antioxidant enzymes and level of glutathione in human erythrocytes. Comp Biochem Physiol C: Toxicol Pharmacol 135:435-441

Chen J, Jiang J, Zhang F, Yu H, Zhang J (2004) Cytotoxic effects of environmentally relevant chlorophenols on L929 cells and their mechanisms. Cell Biol Toxicol 20:183-196

Don RH, Pemberton JM (1985) Genetic and physical map of the 2,4D degradative plasmid pJP4. J Bacteriol 161:466-468

Goodman JE, Loftus CT, Zu K (2015) 2,4-Dichlorophenoxyacetic acid and non-Hodgkin's lymphoma, gastric cancer, and prostate cancer: meta-analysis of the published literature. Ann Epidemiol 25:626-636

Gorzinski FJ, Kociba RJ, Campbell RA, Smith FA, Nolan RJ, Eisenbrandt DL (1987) Acute pharmacokinetic and subchronic toxicological studies of 2,4-dichlorophenoxyacetic acid. Fund Appl Toxicol 9:423-435

Kim HJ, Park YI, Dong MS (2005) Effects of 2,4-D and DCP on the DHT-induced androgenic action in human prostate cancer cells. Toxicol Sci 88:52-59

Laurent F, Canlet C, Debrauwer L, Pascal-Lorber S (2007) Metabolic fate of [(14)C]-2,4-dichlorophenol in tobacco cell suspension cultures. Environ Toxicol Chem 26:2299-2307

Li H, Zhang X, Qiu Q, An Z, Qi Y, Huang D, Zhang Y (2013) 2,4dichlorophenol induces apoptosis in primary hepatocytes of grass carp (Ctenopharyngodon idella) through mitochondrial pathway. Aquat Toxicol 140:117-122

Liao Y, Zhou X, Kuai B (2006) The key role of chlorocatechol 1,2dioxygenase in phytoremoval and degradation of catechol by transgenic Arabidopsis. Plant Physiol 142:620-628

Lurquin PF (2001) The green phoenix: a history of genetically modified plants. Columbia University Press, New York

Lurquin PF (2002) High tech harvest: understanding genetically modified food plants. Westview Press, Boulder

Lyon BR, Llewellyn DJ, Huppatz JL, Dennis ES, Peacock WF (1989) Expression of a bacterial gene in transgenic tobacco plants confers resistance to the herbicide 2,4-dichlorophenoxyacetic acid. Plant Mol Biol 13:533-540

Ma Y, Han J, Guo Y, Lam PK, Wu RS, Giesy JP, Zhang X, Zhou B (2012) Disruption of endocrine function in in vitro H295R cellbased and in in vivo assay in zebrafish by 2,4-dichlorophenol. Aquat Toxicol 106:173-181

National Toxicology Program (1989) NTP toxicology and carcinogenesis studies of 2,4-dichlorophenol (CAS No. 120-83-2) in F344/N rats and B6C3F1 mice (feed studies). Natl Toxicol Progr Tech Rep Ser 353:1-182 http://www.ncbi.nlm.nih.gov/pubmed/ 12704431

Perkins EJ, Stiff CM, Lurquin PF (1987) Use of Alcaligenes eutrophus as a source of genes for 2,4-D resistance in plants. Weed Sci 35(Suppl. 1):12-18

Perkins EJ, Bolton GW, Gordon MP, Lurquin PF (1988) Partial nucleotide sequence of the chlorocatechol degradative operon 
tfdCDEF of pJP4 and similarity to promoters of the chlorinated aromatic degradative operons $t f d A$ and $c l c A B D$. Nucleic Acids Res 16:7200

Perkins EJ, Gordon MP, Caceres O, Lurquin PF (1990a) Organization and sequence analysis of the 2,4-dichlorophenol hydroxylase and dichlorocatechol oxidative operons of plasmid pJP4. J Bacteriol 172:2351-2359

Perkins EJ, Sekine M, Gordon MP (1990b) Metabolism of 2,4dichlorophenol in tobacco engineered with bacterial degradative genes. Plant Physiol (Suppl.) 93:1http://www.osti.gov/scitech/ biblio/5850788

Streber WR, Willmitzer L (1989) Transgenic tobacco plants expressing a bacterial detoxifying enzyme are resistant to 2,4-D. Nat Biotechnol 7:811-816

Syracuse Research Corporation (1992) Toxicological profile for 2,4dichlorophenol. US Dept. of Health and Human Services TP-91/ $14 \mathrm{http} / / /$ babel.hathitrust.org/cgi/pt?id=uc1.32106012858244;view $=1 \mathrm{up} ; \mathrm{seq}=12$
Taylor SG, Shilling DG, Quesenberry KH, Chaudhry GR (1989) Phytotoxicity of 2,4-D and 2,4-dichlorophenol to red clover (Trifolium pratense). Weed Sci 37:825-829

Wright TR, Shan G, Walsh TA, Lira JM, Cui C, Song P, Zhuang M, Arnold NL, Lin G, Yau K, Russell SM, Cicchillo RM, Peterson MA, Simpson DM, Zhou N, Ponsamuel J, Zhang Z (2010) Robust crop resistance to broadleaf and grass herbicides provided by aryloxyalkanoate dioxygenase transgene. Proc Natl Acad Sci USA 107:20240-20245

Zhang X, Li H, Qiu Q, Qi Y, Huang D, Zhang Y (2014) 2,4Dichorophenol induces global DNA hypermethylation through the increase of S-adenosylmethionine and the upregulation of DNMTs mRNA in the liver of goldfish Carassius auratus. Comp Biochem Physiol C: Toxicol Pharmacol 160:54-59 